\title{
喉頭腫瘍に対するレーザーの応用 \\ The Application of LASER Surgery to Carcinoma of Larynx
}

\author{
井上鐵三，友松英男，小倉雅実，坂田淳一 \\ Tetsuzo Inoue, Hideo Tomomatsu, \\ Masami Ogura, Junichi Sakata
}

防衛医科大学校 耳鼻咽㬋科

National Defense Medical College

近年レーザー手術の発達普及に併って，頭頸部 癌にもレーザーが利用されるようになってきた。 特に耳鼻咽喉科領域では, 喉頭癌, 舌癌によく利 用されている。レーザーは, 大変有用な手術手段 の一つであるが，容易な手術手段であるだけに， 適応の決定，使用法の設定は敩格であらねばなら ない。平野らが言うようにレーザーの専門家が頭 頸部癌を治療するのではなく, 頭頸部癌の専門家 が正しくレーザーを用いる事が重要であり，レー ザーは決し、て魔法の杖でない事を肝に銘ずる必要 第 5 巻第 3 号 1985 年 1 月
がある。

私たちが，喉頭癌に用いているレーザーは主に $\mathrm{CO}_{2}$ レーザーと $\mathrm{CO}_{2}+\mathrm{YAG}$ 混合レーザーであ る。当科に招いて昭和 57 年 10 月から昭和 59 年 9 月までに得られた喉頭尰瘍の治療方法及び成績に ついて述べる。

対 象

昭和 57 年 10 月から昭和 59 年 9 月まで 21 カ月に喉頭癌 22 症例, 35 手術例を経験した。 
（全て新鮮例ではなく他院での放射線治療後の再 発を含む。)

症例は T 1, T 2 で初診時, 手術可能と判定さ れた症例であり，原則としてNO，MOであるが 頸部リンパ節転移のある症例でも, Neck dissection で完全摘出可能な症例でもレーザー手術 を行った。（N1 3 例，N2 1 例）

男女比は男性 20 人，女性 2 人と $10 ： 1$ であ った。腫演の発生部位は表 1 の通りであり主に声 門癌を対象とした。

\section{表 1 腫 瘍 部 位}

\begin{tabular}{ll}
\hline Rt. cord & 8 \\
Lt. cord & 8 \\
Rt. ventricular band & 1 \\
Anterior commissure & 4 \\
Posterior commissure & 4 \\
Arytenoid area & 2 \\
Subglottic space & 2 \\
Supraglottic space & 2
\end{tabular}

初診時T. N. M分類は表 2 の通りであり，T 2 症例 2 例は, 放射線, レーザー手術併用療法を行 ったがコントロールできず，喉頭全摘出術を施行 した。

\section{表 2 T.N. M. 分 類}

\begin{tabular}{lrrrrr}
\hline Tis & 1 & Tla & 11 & Tlb & 6 \\
T2 & 4 & & & & \\
N0 & 19 & N1 & 8 & N2 & 1 \\
M0 & 22 & & & &
\end{tabular}

治療方法および治療成績

喉頭癌の治療の中で，レーザー手術をどの時点 で導入するかは，各施設で異なり，幾つかの案が 述べられてきた。

当科に括いても，放射線治療との併用療法，レ ーザー手術単独療法を行った。放射線照射後レー ザー手術例 15 例，レーザー手術後放射線照射例 4 例，レーザー手術単独療法 3 例である。
放射線外照射線量は表 3 の通りである。50Gy 以上の照射もあるが，最近当科では $20 \sim 30 \mathrm{~Gy}$ の照射と少ない傾向にある。

\section{表 3 外照射線 量}

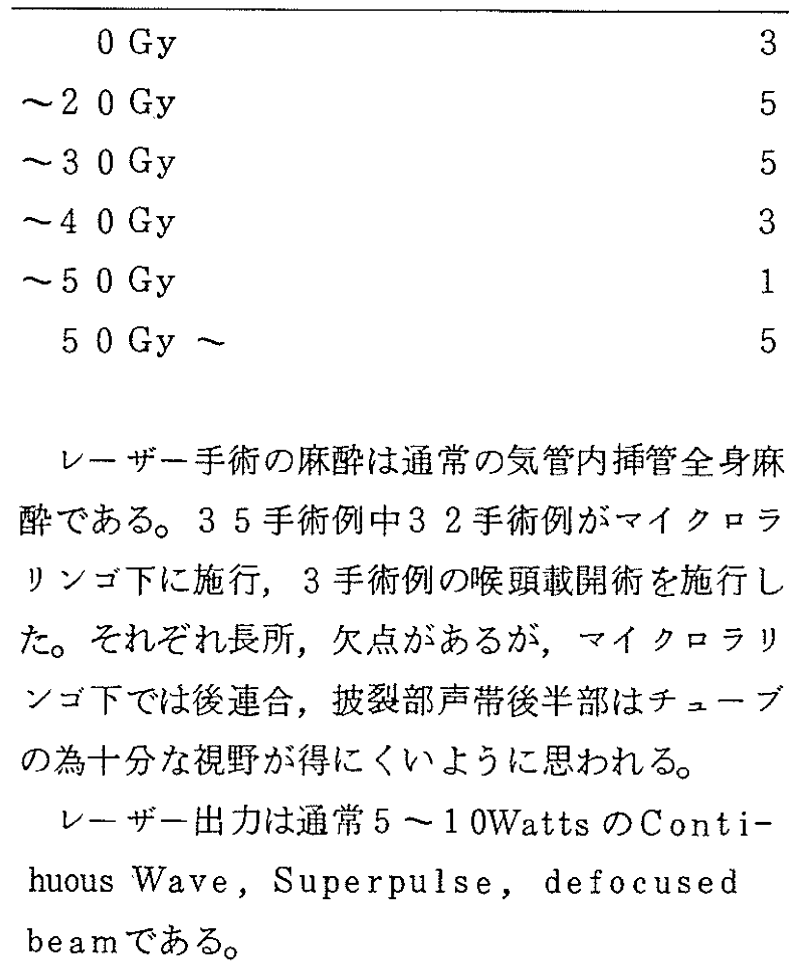

表 4 に手術例のレーザー出力を示す。最近は出 血量，時間節約から高出力の傾向になっている。

表 4 レーザー出力

\begin{tabular}{rr}
\hline $5 \sim 10$ Watts & 17 \\
$10 \sim 15$ Watts & 13 \\
$15 \sim$ Watts & 5
\end{tabular}

切除, 蒸散方法は, マイクロラリンゴ下て鉗子を 用い腫湟の進展範囲を把握し, 腫瘍周囲の健常組 織からレーザー照射を行う。腫瘍中心からレーザ 一照射を行うと, 腫瘍進展範囲が不明確になりや すい。又, 術前照射例では初診時の進展範田がわ かりにくく, レーザー手術後, 再発, 残存する例 が多い。

マイクロラリンゴ下でのレーザー手術において 出血, 炭化は大きな手術障害となる。動脉性出血 の時は，吸引管の先端で電気凝固を行い止血して いる。排煙処理は，私たちは，喉頭鏡に 2 ケのチ 
ヤンネルを用意し，その内 1 ケを排煙専用に用い ている。覒管チューブの保護, 健常組織の保護に は, キシロカインで湿らせた小ガーゼで行ってい る。

術前に得られた病理組織分類は，表 5 の通りあ る。

\section{表 5 病理組織分類}

\begin{tabular}{lll}
\hline Well differentiated & $\begin{array}{l}\text { squamous cell } \\
\text { carcinoma }\end{array}$ & 17 \\
Poorly differentiated & squamous cell & \\
& carcinoma & 2 \\
Mucoepidermoid & carcinoma & 1 \\
Spindle cell carcinoma & & 2
\end{tabular}

術後必ず試験切除を行うが，術直後であると artifactが多くみられる。又，数日で厚いフィ ブリンがお括い，腫瘍残存を見逃す危険性がある。 腫瘍残存がある場合，再手術を施行しているが， 何回施行できるかは検討されるべきである。麻醉 による肝蔵への負担もある。更に重要な事は，腫 瘍は確実に増殖しているのである。他の治療方法 の成績より劣るようなら思いきって治療プログラ ムを変更する。 当科での手術回数を表 6 に示す。

\section{表 6 手術回 数}

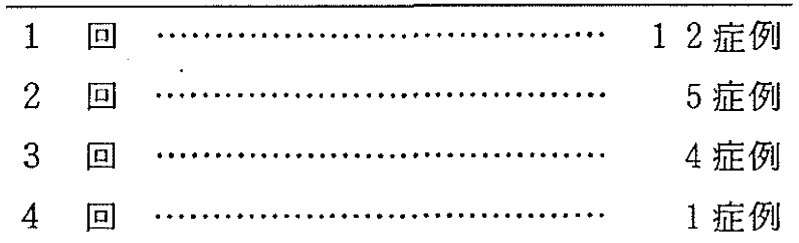

一症例，1回から最高 4 回，平均手術例 1.7 回 である。

3 回以上の内訳は，声門癌の $\mathrm{Tla} 1$ 例， $\mathrm{T} 1 \mathrm{~b}$ 2 例， T2 1 例，声門上癌 Tla 1 例であり， 内 2 例は喉頭全摘出術で見在，コントロールでき ている。

現在までの治療成績は表 7 の通りである。

\section{表 7 治癋状況}

cure rate $19 / 22$

cleath rate

$2 / 22$

Total laryngectomy 3

Recurrence and incomplete removal 1

死亡例 2 例中， 1 例は早期に肺おるよび肝転移に よる。他 1 例は，頸部リンパ節転移によるもので あった。

再発および残存例は，声門癌 T1bでありレーザ 一単独療法 4 回施行後, 現在放射線照射でコント ロールされている。

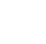

